\title{
Get In Rhythm Before Class
}

Doralee R. White, (E-mail: white3dr@cmich.edu), Central Michigan University

Joseph E. Finck, Central Michigan University

\begin{abstract}
Music may be played before class to introduce material, to consider current events, or to reflect on historical happenings of that day. The response from students is overwhelmingly positive.
\end{abstract}

\section{INTRODUCTION}

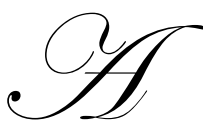

academic activities are occurring.

The times before and after class are valuable instructional periods and it is a good practice for faculty to arrive before the start of class and remain until all the students have left. These are good opportunities to resolve those "I just have one quick question" issues. In introductory physics courses, faculty typically arrive early to set up demonstrations This is an ideal time to throw in a CD so that the incoming students are greeted with music. The practice of playing music before physics class in particular was discussed in a previous article (ref.1).

In the fall of 1979 one of the authors of this paper (J. F.) was a graduate teaching assistant in a college physics course at Michigan State University. Every week, the class had two recitations and two lectures. The recitation sections were led by graduate students, while the lectures were presented to seven hundred students by a physics department faculty member. During that particular semester, Professor William Hartmann directed the course and was responsible for preparing and presenting the large lecture component of the class.

Professor Hartmann specializes in musical acoustics, signal processing, and psychoacoustics. While he was setting up demonstrations and preparing his presentation before class, he would play music. His daily selections were either classical pieces, or electronic music that professor Hartmann composed. The students in the class enjoyed both forms of music very much, even though the songs were quite unfamiliar or even foreign to them.

In the mid eighties one of the authors (J. F.) was assigned to teach college physics at Central Michigan University. He put together a turntable, amplifier, and speaker on a large cart and copied the practice of playing music that he learned from Professor Hartmann. This concept was refined by using music that related to the physics curriculum, academic calendar, and current or historical events. The response from the students has been overwhelmingly positive. They enjoy the music played and the atmosphere it creates in the classroom; they even anticipate how the music will connect to class.

While the curriculum of a physics class is an ideal match for many musical pieces, classes in any college discipline could successfully use music before class to enliven the students and introduce material. This paper discusses previous studies that have identified general benefits of playing music, particularly during or before class. The paper describes how today's technology and classrooms are adapted to easily allow the playing of music. The importance of selecting appropriate and connecting songs is explained. Finally, a survey conducted in four large lecture classes measures the student response and reaction to the practice of playing music before physics class. 


\section{RELATED STUDIES}

The primary motivation for playing music before physics class at Central Michigan University has always been to have fun. Introducing and reinforcing physics topics is simply part of making the class enjoyable for all. We have never had an ulterior motive to make the students smarter, change their music listening habits, or train their brains. We are, however, well aware of the flurry of research in the past decade in response to the attention given to the "Mozart Effect."

Listening to Mozart has been credited with increased mathematical and verbal skills. Research has shown a link between music and spatial intelligence. In addition, other studies find that listening to Mozart increases spatial intelligence but the effects last for only ten to fifteen minutes (ref.2). It is important to note that a follow up study has given mixed results for the Mozart Effect (ref. 3) prompting the original study to be repeated. This more extended project compared the effect of silence, popular dance music, and Mozart. Mozart's music was again found to increase spatial intelligence (ref. 4).

The Mozart Effect is often misunderstood by the public. The original studies have not been limited to compositions by one author. It has shown that Baroque music in general, with a tempo of 50-70 beats per minute, is optimal for learning (ref. 5). In addition, the Mozart Effect's research findings are often oversimplified to imply that simply listening to Mozart will make you smarter. With the discovery that listening to Mozart does not make you smarter, much of the public has rejected anything to do with listening to classical music (ref. 6).

Listening to music has been shown to have positive effects beyond increasing the listener's spatial intelligence. Efficiency increases of over twenty percent have been accredited to music playing by companies as diverse as manuscript editing businesses and power company offices (ref. 7). If background music is played while learning something, listening to the same music is the best way to recall the information. Using slow jazz, fast jazz, slow classical and fast classical, the ability to recall information has always been better when the music remained the same and worse when the music was different (ref. 8). If the words to a song relate to something one is trying to remember, it is often much easier to recall the information. Individuals may not know what letter comes after $\mathrm{Q}$ off the top of their head, but it only takes a few seconds to recite the melody of the alphabet song (ref. 9). One study shows that the type of music played influences the time for rats to navigate a maze. At the start, the average time for all mice to complete the maze was ten minutes. They were then divided into three groups. One group was exposed to no music. The remaining two listened to either hard rock or Mozart ten hours a day. Over several weeks the group that did not listen to any music improved their time by five minutes. The group that listened to Mozart improved by eight and a half minutes, but the hard rock group added about twenty minutes to their time (ref. 5).

Music also has the ability to measurably influence health. Listening to music has been shown to increase levels of interleukin-1 (IL-1) in the blood from 12.5 to 14 percent. These proteins are associated with blood and platelet production, lymphocyte stimulation and cellular protection against AIDS, cancer and other diseases (ref. 10). In addition, the type of person hearing the music has a greater impact on the production of cortisol stress hormones than the type of music played. One study shows that there is a much bigger difference in the reaction of biology students compared to music students than there is between fast and slow songs. Music students appear to be more engaged by the music whether it was fast or slow, and their cortisol increased. The biology students show a decrease in cortisol independent of the music pace, which is consistent with most other research results (ref. 11).

People have physical reactions to music. Music has the ability to produce physical changes such as chills and tingles. In a survey of British adults (ref. 12) more than eighty percent reported that music caused physical responses such as thrills, laughter, tears, or a 'lump in the throat' feeling. Music has a way of bringing back memories or emotions and can often be mood altering.

Background music can be used effectively to alter someone's mood. One example is a study using paintings, viewed with different types of background music playing. Often the interpretation of the mood of the painting and music is found to be similar to the mood interpreted by experts. The interesting part is that when broken down, the music often changes the mood of the painting, but the painting does not seem to alter the mood of the music. (ref. 13) 
Retailers are aware of the impact of background music. One study shows the use of slow music increases sales compared to fast music by $39.2 \%$ in a national chain of supermarkets (ref. 14).

Many teachers have found that music can improve their students' attitudes and social behaviors. "Seventh and eighth grade students in Los Angeles were involved in a curriculum involving music and other arts. Compared to control classes having standard social studies curricula in a Los Angeles middle school, classes where music was played had higher achievement grades in history, and significant increases in positive social behaviors. This includes helping and sharing, increases in empathy for others, and beneficial attitudes including reduced prejudice and racism. Teachers also have found that students are less aggressive (ref. 15). A teacher in a high school chemistry lab heard that music could help improve coordination and concentration. Some of the students were struggling to complete the labs. When background music was introduced, students had an almost immediate, positive reaction. They calmed and quieted down almost as soon as they entered the classroom and the students were able to complete the lesson. These results continued for the rest of the semester (ref. 5).

Music can be used to improve the atmosphere in the classroom. Background music can be utilized to help reduce distracting sounds such as construction or lawn mowing. When choosing the volume to play in the classroom it is important to keep in mind that 15 to 25 percent of the students may be highly sensitive to sounds. (ref. 9) Observations of two neighboring college classrooms, one with and the other without music, showed dramatic differences. Students in the classroom without music playing sit quietly and stare forward while they wait for class to start. Students in the room where the music played before the start of class interact and engage in conversation (ref. 14). Instructors find that it is important to match the music with the atmosphere they are trying to create and connect the music to the curriculum. This can be done by playing different songs or types of music on different days. One instructor suggests using songs like "Take Me Home Country Road" to close the day or the theme to "Jeopardy" when assigning a task. (ref. 15) A high school social studies teacher finds the use of rock and roll in the classroom very beneficial. This type of music provides students with a new way to approach information; it allows the classroom to expand beyond the limitations of the textbook, since many rock and roll songs include history and social issues (ref. 16).

\section{THE BEFORE CLASS MUSIC FORMAT}

Today's university classrooms, especially lecture halls, are typically mediated. One may find a rack of audio and video equipment or a built in desktop computer. Both systems are capable of playing a CD or DVD and the audio quality is usually quite good. Even if a classroom is not mediated, computers on carts or laptops with CD/DVD players are common. As a result, it is easy for an instructor to slide in a CD and quickly select a track to start a music selection.

Before the start of class, a CD is selected which contains a song that can related to the physics topic of that day or an event — current or historical—of that date. The music is played up to the start of the class and an attempt is made to always end with the "song of the day."

An extensive library of music has been accumulated to choose the "song of the day." A variety of music is available and they are listed below with largest collections first:

\begin{tabular}{ll} 
- & Classic rock \\
- & Country \\
- & Classical \\
- & Jazz \\
- & Musicals \\
\hline & Popular
\end{tabular}

Although classic rock and roll is played the most, an effort is made to mix up the genres. This expands the number of titles available and exposes the students to musical styles that they may not be accustomed to hearing. 
Care is taken to avoid inappropriate songs. Some lyrics do have offensive language. A classic example of this is "We Can Be Together" by the Jefferson Airplane, which embarrassed the producers of the Dick Cavett show in 1969 [ref. 19]. And, of course, rap music is notorious for lyrics that are disturbing to various segments of the population. In addition, many songs with titles related to physics topics are love songs with sexually suggestive lyrics that may be misinterpreted when a college professor plays them for his class (e.g., "Light My Fire" by the Doors). Finally, if students walk in during the middle of a song that is not familiar to them, the lyrics may seem quite strange (e.g., "Alice's Restaurant" by Arlo Guthrie).

\section{MUSIC FOR THE PHYSICS CLASS}

Over 160 songs matching physics topics have been tabulated and may be found at a website (ref. 20) maintained by the authors. Playing music before a physics class in particular was discussed in detail in a previous publication (ref. 1). Generally, it is quite easy to pick a "song of the day" for physics class, because the topics naturally match so many songs. This is particularly true for heat, light, astronomy (moon, sun, and planets), the motion of, and forces on, moving objects (trains, planes, and automobiles). There are also compact discs ("albums") with physics topics in the title ("The Planets" by Gustav Holtz) or in the name of the performing group (The Electric Light Orchestra). Other disciplines, such as history, also offer many choices for music. A course in western civilization could play music that was composed during the historical period discussed for that day; and a wealth of material is available for a course about Vietnam. On the other hand, there are disciplines, such as math and accounting, where it could be quite challenging to match the music with the curriculum. When it is difficult to make the connection, there are other song categories that may be used.

\section{MUSIC FOR EVENTS AND OCCASIONS}

Sometimes there are physics topics for which we have not found many songs that connect to the curriculum. This is particularly true when atomic and quantum physics are covered. In addition, there are occasions in the academic and Julian calendars and daily events that occur (hurricanes, team victories or losses, elections) and that trump the physics topic of the day. For example, on the last day to withdraw from class, "With You or Without You" by U2 is played. Similarly, on both November 22 and January 15, "Abraham, Martin, and John" is always the song of the day. And on the first day of spring, "Appalachian Spring" by Aaron Copland greets the students as they arrive. In addition, one can always celebrate the anniversary of the birth or death of Elvis, Mozart, Miles Davis, Patsy Cline, or John Lennon. The students seem to appreciate this variety and since they are typically isolated college students, their physics class can become a source for current events and historical perspectives. Sample songs for the academic calendar, Julian calendar, and general events are shown in tables 1, 2, and 3 respectively.

There are times when students need a little history lesson to appreciate the song of the day. Two good examples of this are "Back in the USSR" by the Beatles, which is played on the anniversary of Sputnik's launch and "Volunteers [for America]," which is used to empathize the significance of the G.I. Bill. In addition, there are times when the music connection is more obtuse such as when the theme song to Star Wars is played on opening day of the baseball season. James Earl Jones was the voice of Darth Vader in Star Wars. He also played important roles in Field of Dreams and The Sandlot - two popular baseball movies. We have observed that students enjoy and are challenged by these convoluted connections.

Table 1A: Songs For The Academic Calendar

\begin{tabular}{|l|l|l|}
\hline Topic & Song & Artist \\
\hline First day of class & Who Are You & The Who \\
\hline Day of a really difficult concept & Think & Aretha Franklin \\
\hline Day of a tricky demonstration & The Magic Touch & The Platters \\
\hline Students want a deadline extension & Dream On & Aerosmith \\
\hline Midterm & Ain't Wastin' Time No More & Allman Brothers Band \\
\hline The day before an exam & Countin' on a Miracle & Bruce Springsteen \\
\hline Minutes before an exam & Any Mozart & Mozart \\
\hline
\end{tabular}




\begin{tabular}{|l|l|l|}
\hline After returning a really hard test & $\begin{array}{l}\text { You Can't Always Get What You } \\
\text { Want }\end{array}$ & The Rolling Stones \\
\hline $\begin{array}{l}\text { Students complain about a hard } \\
\text { exam }\end{array}$ & Whiney, Whiney & Willi One Blood \\
\hline Last day to withdraw & With You or Without You & U2 \\
\hline Last week of class & Desperado & Linda Ronstadt \\
\hline Last day of class & School's Out & Alice Cooper \\
\hline
\end{tabular}

Table 1B: Songs For The Julian Calendar

\begin{tabular}{|l|l|l|l|}
\hline Month & Event & Song & Artist \\
\hline September & Equinox & The Four Seasons, Fall & Vivaldi \\
\hline \multirow{3}{*}{ October } & $\begin{array}{l}\text { Sputnik launched Oct. 4, } \\
1957\end{array}$ & Back in the USSR & The Beatles \\
\hline & Homecoming & My Old School & Steely Dan \\
\hline & Halloween & Halloween & Rent Soundtrack \\
\hline November & Day before the election & Express Yourself & Charles Wright \\
\hline & Your candidate wins & Joy to the World & Three Dog Night \\
\hline & Your candidate loses & Drown in My Own Tears & Ray Charles \\
\hline & Great American Smoke out & Hard Habit to Break & Chicago \\
\hline January & JFK Assassinated on the & Abraham, Martin \& John & \multirow{2}{*}{ Dion } \\
\hline February & Thanksgiving & Arlo Guthrie \\
\hline March & MLK Day & Alice's Restaurant & Dion \\
\hline & Valentine's Day & Abraham, Martin \& John & Sarah Vaughan \\
\hline & Week before spring break & The Wanny Valentine & The Beach Boys \\
\hline & St. Patrick's Day & Any Celtic Music & \\
\hline April & Equinox & Long Day Comin' & Hal Ketchum \\
\hline \multirow{2}{*}{ May } & Spring & Appalachian Spring & Aaron Copland \\
\hline & April Fool's Day & Chain of Fools & Aretha Franklin \\
\hline
\end{tabular}

Table 1C: Songs For General Events

\begin{tabular}{|l|l|l|}
\hline Topic & Song & Artist \\
\hline $\begin{array}{l}\text { Politician or university president } \\
\text { gives a speech }\end{array}$ & Suspicious Minds & Elvis Presley \\
\hline $\begin{array}{l}\text { President, Provost, Dean, Football } \\
\text { Coach, Secretary of Defense is } \\
\text { fired/resigns }\end{array}$ & Hit the Road Jack & Ray Charles \\
\hline Professor feels old & My Generation & The Who \\
\hline Faculty contract & Ain't too Proud to Beg & The Temptations \\
\hline Eclipse & Total Eclipse of the Heart & Nicki French \\
\hline Weather & Oh, What a Beautiful Mornin' & Oklahoma! Soundtrack \\
\hline & Lovin' a Hurricane & Suzy Bogguss \\
\hline & Hell Freezes Over & The Eagles \\
\hline & The Thunder Rolls & Garth Brooks \\
\hline & Shower the People & James Taylor \\
\hline & On the Sunnyside of the Street & Louis Armstrong \\
\hline Earthquake & I Feel the Earth Move & Carol King \\
\hline Moon & How High the Moon & Sarah Vaughan \\
\hline & It's Only a Paper Moon & Bud Freeman \\
\hline Planets & The Planets Gustav Holst & Gustav Holst \\
\hline Days of the & Week Come Monday & Jimmy Buffett \\
\hline
\end{tabular}




\begin{tabular}{|l|l|l|}
\hline & Monday, Monday & The Mamas \& The Papas \\
\hline & Tuesday Afternoon & The Moody Blues \\
\hline Wedding & Wedding March & Mendelssohn \\
\hline & The Marriage of Figaro & Mozart \\
\hline
\end{tabular}

At Central Michigan University, a Student Opinion Survey is always conducted in the last week of the semester. Through this venue, unsolicited written student comments about the music before class have appeared on over ten percent of the responses. Without exception, these remarks have always been positive. A sample is given below:

- $\quad$ I really liked the music that was played at the beginning of class; it was a nice change of pace for the day.

- $\quad$ I really enjoyed the music every morning; it gets you going at such an early time.

- $\quad H o p e$ you don't mind but I'm stealing your idea with the music at the beginning of class. It's a great attention getter!

- $\quad$ Music before class helps me to concentrate on work later, so that was a good idea.

- $\quad$ I liked the music at the beginning. It really kick starts the day.

In an attempt to measure the students' reactions to the music, a survey was constructed. The surveys were given at the end of the semester to students in four different large lecture classes taught by Professor Finck. The surveys were given well before student opinion surveys were conducted and the anxiety of final exams. The audiences were quite different as described below:

- $\quad$ The Survey of Physical Science course introduces students to the nature of the physical universe, the concepts and methods of physical science, and the history of scientific ideas. Over 100 students are enrolled in this lecture and demonstration class. All the students are non-science majors looking to fulfill a general education science requirement. Very few students enroll in the class because they find the topic interesting.

- $\quad$ The Physics of Sports course is also a large lecture class that could be used to satisfy the general education science requirement. The course uses sports to introduce students to some of the basic laws physics. While many of the one hundred plus students who register for the class like sports, few admit to liking physics.

- The College Physics I is an algebra-based introductory physics course that covers motion, forces, energy, vibrations and thermal effects. Primarily biology and health science majors take the class, and at the start of the semester it has an enrollment of about 180 students. It is an important requirement for students in preprofessional programs (pre-physical therapy, pre-med, pre-dent, and pre-vet). Many of these students are accustomed to hard work in their core science curriculum. A substantial fraction of the class is motivated to achieve high grades. As a result, they have high expectations for their science education.

- $\quad$ College Physics II is a continuation of the previous course. The class covers electricity, magnetism, optics, and modern physics. The enrollment is typically over a hundred students. Other than the material covered, the main difference between the two college physics courses is that the weaker students have been weeded out by the second semester.

Table 2 shows that there is a good distribution of gender and grade levels in the classes surveyed. The majority of the students are sophomores and juniors, this is predictable in general education and service science classes. As expected, there were no freshmen in the second college physics course. This course is taught in the fall semester and the first college physics course is a prerequisite. A quarter of the students are juniors and another quarter are seniors or beyond. This is important to note because these upper level students are expected to be the most jaded in their responses to a required course that is not in their major or minor departments. 
Table 2: Class Standing And Gender Of Students In The Four Classes

\begin{tabular}{|l|c|c|c|c|c|}
\hline & $\begin{array}{c}\text { Survey of } \\
\text { Physical } \\
\text { Science }\end{array}$ & $\begin{array}{c}\text { Physics of } \\
\text { Sports }\end{array}$ & $\begin{array}{c}\text { College Physics } \\
\text { I }\end{array}$ & $\begin{array}{c}\text { College Physics } \\
\text { II }\end{array}$ & Total \\
\hline Freshmen & 5 & 13 & 16 & 0 & $34(11 \%)$ \\
\hline Sophomore & 29 & 31 & 50 & 3 & $117(36 \%)$ \\
\hline Junior & 12 & 18 & 15 & 24 & $87(27 \%)$ \\
\hline Senior & 8 & 5 & 8 & 27 & $55(17 \%)$ \\
\hline Senior + & 7 & 3 & & & $30(9 \%)$ \\
\hline & & & 62 & 33 & 12 \\
\hline Male & 25 & 41 & 60 & 37 & $161(50 \%)$ \\
\hline Female & 36 & 29 & & & $750 \%$ \\
\hline
\end{tabular}

The response of the students to the general practice of playing music before class is displayed in Table 3 . This is perhaps the most important question in the survey. It shows an overwhelming $97 \%$ of the students enjoy the music, while only two students out of 323 dislike the music. There are few classroom techniques that receive such a positive response.

In addition to the favorable reception that the students give to the music before class, the other important result is the similarity in responses between the classes for this question. Indeed, for all subsequent survey questions, the responses are nearly identical. Since the sample size in each class is large, it is valid to aggregate the data.

Table 3: Responses By Students To The General Practice Of Playing Music Before Class

\begin{tabular}{|l|c|c|c|c|c|}
\hline Course & $\begin{array}{c}\text { Physical } \\
\text { Science }\end{array}$ & $\begin{array}{c}\text { Physics of } \\
\text { Sports }\end{array}$ & $\begin{array}{c}\text { College } \\
\text { Physics I }\end{array}$ & $\begin{array}{c}\text { College } \\
\text { Physics II }\end{array}$ & $\begin{array}{c}\text { Response } \\
\text { Total }\end{array}$ \\
\hline Number of students responding & 61 & 71 & 121 & 71 & 324 \\
\hline A. I like and enjoy it & 57 & 59 & 114 & 63 & $90.4 \%$ \\
\hline B. Somewhere between A\&C & 1 & 9 & 6 & 6 & $6.8 \%$ \\
\hline C. I can take it or leave it & 2 & 3 & 1 & 1 & $2.2 \%$ \\
\hline D. Somewhere between C\&E & 0 & 0 & 0 & 1 & $0.3 \%$ \\
\hline E. I find it annoying & 1 & 0 & 0 & 0 & $0.3 \%$ \\
\hline
\end{tabular}

Table 4 shows the students' reaction to the different types of music played. The students clearly enjoy rock music the most. Jazz, popular and classical music are all enjoyed by about three-quarters of the class. Even musicals and country music receive approval by over sixty percent of the students. There is no form of music that the majority dislikes and the largest negative response was to country music with only eighteen percent of the students responding negatively.

Table 4: Percent Of Students Responding To The Types Of Music Played

\begin{tabular}{|l|c|c|c|c|c|c|}
\hline & Rock & Jazz & Popular & Classical & Musicals & Country \\
\hline A. I like and enjoy it & 70.8 & 56 & 61.3 & 55.4 & 41.7 & 42.8 \\
\hline B. Somewhere between A\&C & 21.5 & 27.4 & 23.8 & 28.3 & 27.2 & 19.4 \\
\hline C. I can take it or leave it & 2.2 & 12.6 & 12.7 & 12.3 & 20.4 & 19.7 \\
\hline D. Somewhere between C\&E & 0.3 & 2.5 & 1.9 & 2.2 & 5.9 & 6.2 \\
\hline E. I find it annoying & 0.3 & 1.5 & 0.3 & 1.8 & 4.9 & 12 \\
\hline
\end{tabular}


The survey also attempted to ascertain the influence of the music on the classroom atmosphere. The responses to these types of questions are given in Table 5. Ninety-seven percent of the students report that the music creates a relaxed, "laid-back" atmosphere. If only classical music is played this would be expected (refs. 4, 20, 21). However, given the raucous nature of many songs and the volume at which they are played, the music still provides a comfortable atmosphere for the student audience. Not surprisingly, the students state that the music enlivens and wakes them up (84\%). It is very surprising to find that $85 \%$ of typically reserved and self-conscious college students find themselves singing, humming, or tapping. The music seems to create an atmosphere where students interact before class. It is common for students to ask one another, "What is this song?" "Who is the artist?" "Do you love jazz?" Another astounding result was that $81 \%$ of the students reported a positive impact on their enthusiasm for learning. It is difficult to think of another teaching technique that has such a positive impact on the students' "enthusiasm for learning."

Out of 324 students who replied, only two percent report being offended by any songs played. This result is not expected since many of the songs connect to controversial topics or politics. Sometimes the music reflects a liberal bias ("Little Lies" by Fleetwood Mac played on the day the president addresses the nation) and many CMU students (a majority in the physical science class) are quite conservative. In a sense of fairness, though, liberals are equally targeted with songs like "Devil with the Blue Dress On" during the Clinton impeachment.

Table 5: Atmosphere Created In Class By The Music; And Emotional And Physical Responses To The Music Students Who Responded “Uncertain” Are Not Included.

\begin{tabular}{|c|c|c|}
\hline Question & Yes $(\%)$ & No $(\%)$ \\
\hline The music sometimes creates a relaxed atmosphere in the classroom. & 96.9 & 1.8 \\
\hline The music sometimes creates a chaotic environment. & 8.6 & 89.5 \\
\hline The music sometimes enlivens and wakes you up before class starts. & 84 & 15.4 \\
\hline The music sometimes stimulates conversation between students before class. & 65.4 & 26.9 \\
\hline The music sometimes helps create a sense of community in the classroom. & 63.8 & 23.8 \\
\hline The music sometimes causes an emotional response (e.g., sadness, joy). & 56.8 & 36.6 \\
\hline Sometimes I find myself singing with, tapping to, or humming the music when it is being played. & 84.6 & 14.2 \\
\hline The music sometimes has a positive impact on your enthusiasm for learning. & 80.6 & 14.8 \\
\hline Have you ever been offended by any song(s) played? & 2.2 & 97.5 \\
\hline
\end{tabular}

The final set of questions on the survey address the academic stimulation of the music. Table 6 shows that an impressive $92 \%$ of the students recognize how the music is related to the physics topic of the day. Perhaps the most gratifying result is the discovery that $80 \%$ of the students are thinking about how the music will relate to the physics topic before they enter the classroom.

Table 6: Music Appreciation And Anticipation

\begin{tabular}{|c|c|c|}
\hline Question & Yes $(\%)$ & No $(\%)$ \\
\hline Do you recognize that the music usually relates to the physics topic of the day? & 92.4 & 5.8 \\
\hline $\begin{array}{l}\text { As you walk into class, sometimes are you curious about how the music selection for that day } \\
\text { relates to the material about to be covered? }\end{array}$ & 79.7 & 19.4 \\
\hline Does the music ever make you think about traditions of other communities or cultures? & 20 & 77.8 \\
\hline Do the songs ever make you appreciate music in general? & 82.8 & 16.3 \\
\hline $\begin{array}{l}\text { Has the music played in class ever made you consider listening to music outside your typical } \\
\text { comfort listening selection? }\end{array}$ & 53.8 & 41.2 \\
\hline
\end{tabular}

There is no attempt to make the music connect to the traditions of other communities or cultures. However, twenty percent of the students reported that this did, in fact, happen. There are a few songs from different countries 
played (e.g., Celtic music on St. Patrick's Day). And there are songs played about different cultures (e.g., "Buffalo Soldier" by Bob Marley played on Columbus' Day). This suggests that if more songs in this vein are played, it could have an impact on cultural awareness.

The students also report that the music has a cross-disciplinary impact. A conscious effort is made to feature a variety of musical styles. First, this is done with the hope that the students will think about cultural diversity through the variety of music they hear. Second, there is a hope that exposing students to different types of music will expand their musical horizons. The survey shows that both of these occur. Eighty-three percent of the students report that it makes them appreciate music in general and 54\% say the music in class makes them consider listening to music outside their typical comfortable listening selections. Clearly, playing music in a science class makes students think about the arts and expands their musical appreciation. One is hard pressed to think of a similar simple classroom practice that has such a cross-disciplinary impact.

\section{CONCLUSION AND SUGGESTIONS FOR FURTHER STUDIES}

The music played before class is overwhelmingly well-received by students in large lecture physics and physical science classes. The students enjoy all types of music played and usually recognize the connection of the song of the day to the physics curriculum. The music creates a relaxed environment conducive to learning, and helps students connect with one another. Neither the instructor, nor any students identified problems with the music before class.

This work raises several issues for further study. It would be worthwhile to explore if music stimulates students to think about social issues or their responsibilities as citizens. It may well be that in the classroom setting students do not listen to the lyrics. Or one may discover that in any environment most young adults are not overly receptive to socially-conscious musical themes. Finally, fifty-four percent of the surveyed students report that the music played in class made them consider listening to music outside their typical comfort listening selections. A follow-up survey could be constructed to determine if they did indeed expand their musical selections, and if the physics classroom experience had influenced this change.

\section{ACKNOWLEDGEMENTS}

Professor William Hartmann from the physics department at Michigan State University is recognized for introducing one of the authors (J. F.) to the idea of playing music before class. The authors also wish to thank Kevin Daum for designing the website. Finally, Claudia Witt and Deborah Finck are recognized for their helpful editorial suggestions.

\section{REFERENCES}

1. White, D. R. and J. E. Finck, Physics Rocks in the Ten Minutes before Class, Proceedings of the 2006 College Teaching \& Learning Conference, January 2-6, 2006, Disney World, Florida.

2. Rauscher, Shaw, and Ky, Nature 1993, 365, 611.

3. $\quad$ Stough, Personality \& Individual Differences, 1994, 17, 695.

4. $\quad$ Rauscher et al., Neuroscience. 1995, 185, 44-47.

5. Lawrence, Dorothy Lockhart. Using Music in the Classroom. Advanced Brain Technologies. http://www.advancedbrain.com/Article Music in Classroom.asp.

6. $\quad$ Weinberger. MuSICA Research Notes. Vol. 7, Iss. 1, 2000. http://www.musica.uci.edu/mrn/V7I1W00.html\#part.

7. University of Washington. Business Music: A Performance Tool for the Office/Workplace 1991. Seattle: Muzak, 1991.

8. Balch, W. R., Bowman, K., and Mohler, L. 1992. Music-Dependent Memory in Immediate and Delayed Word Recall. Memory \& Cognition. 20, 21-28.

9. Jensen, E. Teaching with the Brain in Mind. Association for Supervision and Curriculum Development. 1998. 
10. Michigan State University as reported in The Mozart Effect, Don Campbell, 1997. (Music)

11. VanderArk, S.D. and Ely, D. 1992. Biochemical and Galvanic Skin Responses to Music Stimuli by College Students in Biology and Music. Percept. Motor Skills. 74, 1079-1090.

12. Slobda, J.A. 1991. Music Structure and Emotional Response: Some Empirical Findings. Psychology of Music. 19, 110-120.

13. Stratton, V.N. and Zalanowski, A.H. 1989. The Effects of Music and Paintings on Mood. Journal of. Music Therapy. 26, 30-41.

14. Milliman, R.E. 1982. Using Background Music to Affect the Behavior of Supermarket Shoppers. $J$. Marketing. 46, 86-91.

15. Konrad, R.R. 2000. Empathy, Arts and Social Studies, Dissertation Abstract. Humanities and Social Science. 60, 2352.

16. Allen, R.H. 2002. Music as One of Your Classroom Strategies. Impact Teaching. Allyn and Bacon, Boston MA.

17. Tracy, K. Sept. 2000. Brain-Compatible Learning Environments: Classroom Enrichment. TEACHERS.NET GAZETTE. Vol. 1 Num. 7. http://teachers.net/gazette/SEP00/tracy.html.

18. Lane, J. Keep on Rockin' in the Free World: The Advantages of Using Rock and Roll in Teaching Social Studies. http://w3.iac.net/ pfilio/lane.htm.

19. Jefferson Airplane. The Dick Cavett Show. August 18, 1969. New York, New York.

20. Daum, K. C. and White, D. R. MIC: Music in the Classroom. http://www.phy.cmich.edu/people/daum1kc/.

21. Escher, J., Hohmann, U., Anthenien, L., Dayer, E., Bosshard, C., and Gaillard, R. C. 1993. Music During Gastroscopy. Schweiz. Med. Wochenschrift. 123, 1354-1358.

22. Giles, M. M. 1991. A Little Background Music Please. PrincipalMagazine. 41-44. 